\title{
THE ONLINE ADVERTISING OF SMALL AND MEDIUM SIZED BUSINESSES
}

\author{
Cristina Bălteanu ${ }^{l}$ \\ Mihaela Marcu ${ }^{2}$
}

\begin{abstract}
The recent decades have brought a new concept, namely the digital communication, which allows information to travel at a much more rapid rate and promotional messages (video, audio or simple texts) to be perceived in real time in different parts of the world. In the online environment, interactivity is the key term, the user being the one who sets up an online profile according to which he gets personalized messages. Thus, the organizations can more easily interact with customers, allocating budgets much lower than those used for traditional media. Therefore, SMEs have a real opportunity to promote themselves in a more efficient manner, at low cost and globally, the Internet offering them the possibility of becoming known among consumers from other states than their home country. In this context, the paper's main objective was the analysis of online advertising market in Europe and also the identification of the main results arising from the implementation of the SMEs promotion campaigns in the virtual environment. The results showed the huge potential of the Internet in terms of online advertising and the main tools that can be used successfully in the efforts of attracting and making customers loyal.
\end{abstract}

Keywords: online advertising, small and medium sized enterprises, social media

JEL Codes: M37, L82, M15

\section{Introduction}

In the last decades the development of the Internet and implicitly the diversification of online advertising methods had a major impact on the advertising industry. Although they do not eliminate the TV, radio and other traditional channels from the marketers' options, it is considered that the future of advertising will depend decisively on the evolution of the virtual environment.

The share of online spend in overall advertising spend depends largely on the product/service offered, as well as the targeted customer segments. Thus, if the public - target consists mainly of young people, the percentage allocated to online promotion is higher, since they are more present in the virtual environment than at TV or radio.

For SMEs the online represents the opportunity to come into contact with both existing and potential customers, using specific tools, in terms of competitive cost, and also high effectiveness and efficiency. In the context of market globalization, ever-rising competition and reduced promotional budgets available to SMEs, the Internet gives them the possibility of making themselves known abroad in a much shorter time than if they would opt for traditional promotional channels. Thus, in the present, the small and medium entrepreneurs have access to an interactive communication medium, which until recently was only used by large companies that allocated significant budgets to be present online.

Taking in consideration the trends in promotion, in this paper was developed a study on the role and importance of the virtual environment in business development, a particular focus being

\footnotetext{
${ }^{1}$ Babeş - Bolyai University of Cluj-Napoca, Faculty of Economic Sciences and Business Administration, cristina.balteanu@econ.ubbcluj.ro

${ }^{2}$ Hyperion University of Bucharest, Faculty of Economic Sciences, mihaela.marcu13@yahoo.com
} 
given to the key indicators of online advertising market, and also to the results obtained by SMEs after the implementation of promotional campaigns through the Internet.

\section{The SMEs in EU}

The problem of developing a common definition of SMEs in Europe was raised for the first time in 1996, and then in 2003 on the background of the evolution Member States' economies, the European Commission initiated new recommendations. The final form of the definition came into force on 1 January 2005, being applied in all policies, programs and measures undertaken by the Commission. According to this definition, the medium sized enterprises employ fewer than 250 persons and have an annual turnover not exceeding EUR 50 million, and/or an annual balance sheet total not exceeding EUR 43 million. Within the SME category, a microenterprise is defined as an enterprise which employs fewer than 10 persons and whose annual turnover and/or annual balance sheet total does not exceed EUR 2 million (European Free Trade Association, 2015) Table 1.

Table 1

The thresholds of the three criteria for determining the type of enterprises

\begin{tabular}{|c|c|c|c|}
\hline $\begin{array}{l}\text { Enterprise } \\
\text { category }\end{array}$ & $\begin{array}{l}\text { Headcount: Annual } \\
\text { Work Unit (AWU) }\end{array}$ & Annual turnover & $\begin{array}{c}\text { Annual balance sheet } \\
\text { total }\end{array}$ \\
\hline $\begin{array}{l}\text { Medium- } \\
\text { sized }\end{array}$ & $<250$ & $\begin{array}{c}\leq € 50 \text { million (in } 1996 € \\
40 \text { million) }\end{array}$ & $\begin{array}{c}\leq € 43 \text { million (in } 1996 € \\
27 \text { million) }\end{array}$ \\
\hline Small & $<50$ & $\begin{array}{l}\leq € 10 \text { million (in } 1996 € \\
7 \text { million) }\end{array}$ & $\begin{array}{c}\leq € 10 \text { million (in } 1996 \\
€ 5 \text { million) }\end{array}$ \\
\hline Micro & $<10$ & $\begin{array}{c}\leq € 2 \text { million (previously } \\
\text { not defined) }\end{array}$ & $\begin{array}{c}\leq € 2 \text { million (previously } \\
\text { not defined) }\end{array}$ \\
\hline
\end{tabular}

Source: European Commission, 2005

Another aspect stated in the definition of the European Commission refers to the fact that SMEs are autonomous, this status being assured by the following situations (Mac an Bhaird C., 2010):

- the enterprise is totally independent;

- the firm owner holds less than $25 \%$ of the capital or voting rights (whichever is higher) in one or more other enterprises and/or outsiders do not have a stake of $25 \%$ or more of the capital or voting rights (whichever is higher) in the enterprise.

For the Member States, the use of definition is optional, but the European Commission, the European Investment Bank (EIB) and the European Investment Fund (EIF) recommend its application as often as possible, the definition having an essential role in facilitating the equity financing of SMEs by granting a favorable treatment to investors.

The particular attention paid to those enterprises by the European institutions is a result of the fact that the more than 20 million SMEs in the EU represent $99 \%$ of businesses, and are a key driver for economic growth, innovation, employment and social integration (European Commission, 2014).

According to statistics, in 2008, before the economic - financial crisis, there were 21,217,051 SMEs in the European Union, which have generated 90,806,273 jobs, and a valueadded at factor costs of 3.62 trillion euros. In 2009, these values decreased significantly, starting with 2010 being recorded positive developments with the exception of the number of SMEs' employees, that in 2013 reached the minimum level of the period analyzed, in relation to which is expected to slightly increase in 2014 (Table 2). 
Table 2

The performances of SMEs in the EU-28 in the period 2008 - 2014

\begin{tabular}{|c|c|c|c|}
\cline { 2 - 4 } \multicolumn{1}{c|}{} & $\begin{array}{c}\text { Number of } \\
\text { enterprises }\end{array}$ & $\begin{array}{c}\text { Number of persons } \\
\text { employed }\end{array}$ & $\begin{array}{c}\text { Value-added at factor costs } \\
\text { (million } \boldsymbol{~} \text { ) }\end{array}$ \\
\hline $\mathbf{2 0 0 8}$ & $21,217,051$ & $90,806,273$ & $3,622,465$ \\
\hline $\mathbf{2 0 0 9}$ & $20,930,961$ & $90,332,632$ & $3,273,276$ \\
\hline $\mathbf{2 0 1 0}$ & $21,712,603$ & $89,933,916$ & $3,425,857$ \\
\hline $\mathbf{2 0 1 1}$ & $21,857,317$ & $90,077,618$ & $3,570,666$ \\
\hline $\mathbf{2 0 1 2}$ & $21,766,554$ & $89,297,328$ & $3,626,206$ \\
\hline $\mathbf{2 0 1 3}$ & $21,571,360$ & $88,843,465$ & $3,666,779$ \\
\hline $\mathbf{2 0 1 4} *$ & $21,521,080$ & $88,981,523$ & $3,769,519$ \\
\hline
\end{tabular}

Source: DIW ECON, 2014

Where: * estimated values

The estimates of the value-added at factor costs, for 2014, ranks Germany on the first place, that, although it has a smaller number of SMEs in comparison with the occupants of the following positions, reported the largest number of employees, namely 17,147,350 people and a value-added at factor costs of 831.69 billion euros. On the second place is France, this being followed by Italy, with 3,634,557 SMEs which generated 11,253,391 jobs and a value-added at factor costs of 455.12 billion. The last position is occupied by Malta (Table 3).

Estimated figures regarding the performance of SMEs in the EU-28 (2014)

\begin{tabular}{|l|c|c|c|}
\hline \multicolumn{1}{|c|}{ Country } & $\begin{array}{c}\text { Number of } \\
\text { enterprises }\end{array}$ & $\begin{array}{c}\text { Number of persons } \\
\text { employed }\end{array}$ & $\begin{array}{c}\text { Value-added at factor costs } \\
\text { (million } \boldsymbol{€} \text { ) }\end{array}$ \\
\hline Germany & $2,254,315$ & $17,147,350$ & 831,694 \\
\hline France & $2,569,972$ & $9,463,389$ & 541,302 \\
\hline Italy & $3,634,557$ & $11,253,391$ & 455,120 \\
\hline UK & $1,746,679$ & $9,741,076$ & 569,671 \\
\hline Spain & $2,229,582$ & $7,548,511$ & 282,007 \\
\hline Netherlands & 797,978 & $3,560,084$ & 192,490 \\
\hline Norway & 287,407 & $1,050,270$ & 156,867 \\
\hline Sweden & 684,181 & $2,065,392$ & 125,072 \\
\hline Belgium & 511,794 & $1,735,308$ & 115,456 \\
\hline Austria & 310,195 & $1,814,786$ & 105,685 \\
\hline Poland & $1,464,234$ & $5,649,064$ & 97,891 \\
\hline Denmark & 214,005 & $1,051,631$ & 81,140 \\
\hline Finland & 220,880 & 884,020 & 51,862 \\
\hline Portugal & 763,569 & $2,224,047$ & 43,892 \\
\hline Czech Republic & $1,014,208$ & $2,430,057$ & 43,764 \\
\hline Ireland & 143,387 & 763,105 & 32,874 \\
\hline Greece & 629,637 & $1,692,880$ & 27,521 \\
\hline Romania & 433,858 & $2,787,483$ & 24,457 \\
\hline Hungary & 525,356 & $1,707,701$ & 24,446 \\
\hline Slovakia & 419,182 & $1,089,598$ & 14,078 \\
\hline Luxembourg & 29,711 & 165,530 & 11,452 \\
\hline Bulgaria & 304,854 & $1,409,054$ & 10,745 \\
\hline Slovenia & 113,349 & 396,911 & \\
\hline
\end{tabular}




\begin{tabular}{|l|c|c|c|}
\hline Croatia & 147,159 & 677,635 & 10,419 \\
\hline Lithuania & 137,936 & 676,351 & 9,676 \\
\hline Latvia & 90,801 & 474,443 & 7,878 \\
\hline Estonia & 60,067 & 312,780 & 7,596 \\
\hline Cyprus & 38,412 & 159,891 & 5,436 \\
\hline Malta & 31,222 & 100,056 & 2,471 \\
\hline
\end{tabular}

Source: DIW ECON, 2014

For 2015, the number of SMEs in the EU-28 is expected to increase, reaching 21,602,971 enterprises and implicitly, the number of employees $(89,585,622)$ and also the value-added at factor costs, which will reach the level of 3.89 trillion euros. In percentage, the growth of total valueadded generated by SMEs will be $3.4 \%$, of the level of employment of $0.7 \%$ and the number of enterprises will increase with $0.38 \%$, the microenterprises recording positive developments superior to the other two (European Commission, 2014).

\section{The online environment - a real channel of promotion for the SMEs}

In the current conditions of a volatile economic environment, the ability to use an intelligent way the information that allows companies to cope with the challenges that they are facing regarding the current economic environment, represents the solution to strengthen their position on the global market (Balint A.O, 2013). In this regard, the online environment has an important role in the expansion of the outlet market of small and medium sized businesses, offering the opportunity of making them known among consumers worldwide with much lower costs than those generated by traditional communication channels.

The evolution of the online environment from the last two decades is based on the continuous development of the Internet, both in terms of number of users and in terms of the amount of information conveyed by using it. Thus, if initially the Internet had a purely scientific purpose, in 1996 it had already more than 35 million users (D. Balaban, 2009), for 2014 being estimated around 3 billion users (International Telecommunications Union, 2014).

The online environment has been also developed in terms of traffic information, a growing number of people actively participating in its development by posting information, uploading and sharing video/audio files, both through social media and by various other applications, covering a wide range of areas. According to the NETCRAFT study (Netcraft, 2015) conducted in February 2015, worldwide, there are over 880 million registered hostnames and 177 million active websites. In addition, Google is the most used search engine in the world and holds an 88 percent share of the market, being followed by Yahoo and Bing, each with about 4 percent share of the search engines market (Statistics, 2015). The average number of daily searches on Google reached 5.7 billion in 2014, 2.095 billion being the total number of searches performed through it last year (Table 4).

Google Annual Search Statistics (1998 - 2014)

\begin{tabular}{|c|c|c|}
\cline { 2 - 3 } \multicolumn{1}{c|}{} & $\begin{array}{c}\text { Annual Number of } \\
\text { Google Searches }\end{array}$ & Average Searches Per Day \\
\hline $\mathbf{1 9 9 8}$ & $3,600,000^{*}$ & 9,800 \\
\hline $\mathbf{2 0 0 0}$ & $22,000,000,000$ & $60,000,000$ \\
\hline $\mathbf{2 0 0 7}$ & $438,000,000,000$ & $1,200,000,000$ \\
\hline $\mathbf{2 0 0 8}$ & $637,200,000,000$ & $1,745,000,000$ \\
\hline $\mathbf{2 0 0 9}$ & $953,700,000,000$ & $2,610,000,000$ \\
\hline $\mathbf{2 0 1 0}$ & $1,324,670,000,000$ & $3,627,000,000$ \\
\hline $\mathbf{2 0 1 1}$ & $1,722,071,000,000$ & $4,717,000,000$ \\
\hline
\end{tabular}

Table 4 


\begin{tabular}{|l|l|l|}
\hline $\mathbf{2 0 1 2}$ & $1,873,910,000,000$ & $5,134,000,000$ \\
\hline $\mathbf{2 0 1 3}$ & $2,161,530,000,000$ & $5,922,000,000$ \\
\hline $\mathbf{2 0 1 4}$ & $2,095,100,000,000$ & $5,740,000,000$ \\
\hline
\end{tabular}

Source: Statistic Brain Research Institute, 2015)

Where: * the first official year of Google

The marketing activities of the SMEs are constrained by many factors such as limited financial resources, inadequate marketing expertise, limited human resources, customer issues etc. (Rusăneanu A. E., 2014). However, they can be successful on their markets, resorting to the use of one or more of online promotional tools, many of them involving lower costs and better results than the traditional ones:

a. The online banners imply the adaptation of the traditional instrument to the virtual environment. They can be: static, presenting a brand, a company or a link to a website, animated, often having a repetitive character, or interactive, implying the use of specific buttons such as , start” or „exit”.

b. The text links are strategically inserted in the sites, the process of accessing them depending entirely on the user. Therefore, they can be highly efficient, presenting a very low degree of "aggressiveness".

c. The advertorials are advertisements in the form of articles which have two purposes, namely: a journalistic and an advertising one. Although many businesses still use banner ads and other forms of advertising, the advertorials have become more and more popular as people recognized its potential in successful marketing and for driving more traffic to a Website (Brown B.C., 2006). Although the generated traffic is no higher than the traffic resulted from using the pay per click method or the promotion through search engines, it has a qualitative character from the perspective of the number of potential clients converted into effective customers. This is because those consumers who visit the site promoted through the advertorial have full confidence in the source that supported and recommended it.

d. The pop-ups are distinct windows that appear when visiting a website or in a few seconds after accessing it. They remain active until they are closed manually by pressing the "close" button. They are considered to be one of the most obstructive online promotional tools, interrupting the user's Internet browsing.

e. The interstitials are ads that appear on a screen while the viewer is waiting for a Website's content to download (Chiagouris L., Mohr I., 2004), being inserted between two pages of content. The more the content of the interstitials is in accordance with that of the site, the more they will be perceived as less intrusive than those that contain irrelevant information to visitors. Also the interstitials without sound effects and animation are considered less aggressive. Unlike pop-ups, interstitials do not interrupt the user's interactive experience because they tend to run while the user waits for a page to download. Users, however, have less control over interstitials because there is no "exit" option to stop or delete an interstitial, which is common among pop-ups. In other words, with interstitials, users have to wait until the entire ad has run (Shimp A., 2013).

f. The sponsorships involve the linking of a brand to certain content or to a relevant context of a web page in order to improve the level of knowledge of it and to strengthen the message sent. They are exposed for a greater period of time than ads.

g. The blogs are websites containing articles posted periodically or continuously updated, in a personal manner.

h. The number of $\boldsymbol{e}$-mail addresses worldwide continued to grow from 3.9 billion in 2013 to 4.1 billion in 2014 and it is projected to reach 5.2 billion in 2018, according to Radicati, 
a research company in the technology field (Table 5). Currently, 23.6\% of the existing e-mail addresses are of global companies and the remaining $72.4 \%$ are e-mail addresses of individuals. Most e-mails (55.4\%) received and transmitted in a day, worldwide, are on business matters. Therefore, the e-mail remains the primary means of communication in business, but also at the level of final consumers, being integrated in all the different processes involved in the online environment (ex.: creating accounts on social networks requires an e-mail address, the inclusion on various websites or online groups requires validation via e-mail etc.). That's why it should be used by SMEs to communicate with potential customers B2B and B2C.

Table 5

The number of e-mail addresses worldwide (2013-2018)

\begin{tabular}{|l|c|c|c|c|c|c|}
\hline Indicators (billions) & $\mathbf{2 0 1 3}$ & $\mathbf{2 0 1 4}$ & $\mathbf{2 0 1 5}$ & $\mathbf{2 0 1 6}$ & $\mathbf{2 0 1 7}$ & $\mathbf{2 0 1 8}$ \\
\hline Worldwide e-mail accounts & 3,899 & 4,116 & 4,353 & 4,626 & 4,92 & 5,235 \\
\hline Business e-mail accounts & 0,929 & 0,974 & 1,022 & 1,078 & 1,138 & - \\
\hline $\begin{array}{l}\text { Total worldwide e-mails sent/received } \\
\text { per day }\end{array}$ & 182,9 & 196,3 & 204,1 & 212,1 & 220,4 & 227,7 \\
\hline Business e-mails sent/received per day & 100,5 & 108,8 & 116,2 & 123,9 & 132,1 & 139,4 \\
\hline
\end{tabular}

Source: The Radicati Group, Inc., 2013a - 2014

i. The social networking sites allow users to relate and meet new people who have the same passions as them. The access to such websites is free and the members can build profiles (which include data on name, age, hobbies or favorite books and movies) and share with others photos, music and videos (Soviany A., 2008).

According to statistics, the social networks are evolving, being estimated an increase from approximately 3.6 billion registered accounts in 2014 to over 5.2 billion accounts by the end of 2018. Most social media accounts are created by individuals for personal information, but there is a clear tendency of the social networks to develop specific tools for business promotion (Table 6).

Worldwide social networking accounts and user forecast (2013-2018)

\begin{tabular}{|l|c|c|c|c|c|c|}
\hline Indicators (billions) & $\mathbf{2 0 1 3}$ & $\mathbf{2 0 1 4}$ & $\mathbf{2 0 1 5}$ & $\mathbf{2 0 1 6}$ & $\mathbf{2 0 1 7}$ & $\mathbf{2 0 1 8}$ \\
\hline Worldwide social networking accounts & 3,190 & 3,615 & 4,078 & 4,459 & 4,861 & 5,258 \\
\hline $\begin{array}{l}\text { Worldwide social networking users } \\
\text { (individuals and companies) }\end{array}$ & 1,091 & 1,202 & 1,319 & 1,443 & 1,573 & 1,709 \\
\hline
\end{tabular}

Source: The Radicati Group, Inc., 2013a - 2014

The number of accounts created for instant messaging via public platforms (Facebook, Google, Microsoft/Skype, Tencent, Yahoo etc.), enterprise IM platforms (Cisco, Good Technology, IBM, Microsoft, Novell and Thomson Reuters etc.) and applications for mobile phones (Apple iMessage, BlackBerry Messenger, WhatsApp Messenger etc.) is projected to increase from 3.4 billion recorded in 2013 to over 4.4 billion in 2017 (Figure 1). Since the number of smartphone users is growing, the software developers act accordingly, so as the mobile phones to integrate all the applications that are available for PCs. 


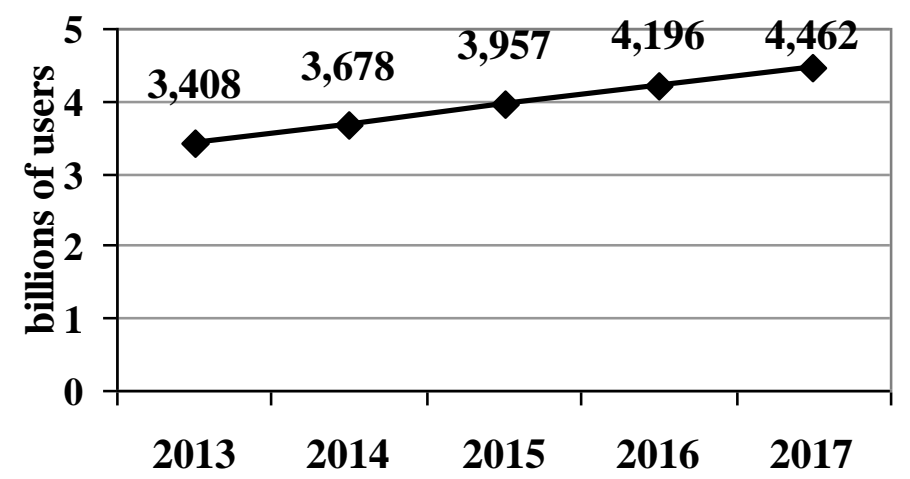

Figure 1. Worldwide IM Accounts, 2013-2017

Source: The Radicati Group, Inc., 2013b

j. The newsletters represent one of the most effective tools of communication in business, their main objective consisting in the familiarization of customers with the company's offer or particular events.

k. The online news sites works basically on the same standards as print media, but they provide many advantages, as a result of the interactivity of messages, these could be linked to other sources of information in order to support the information delivered (Marin V., 2007).

Data on how SMEs use the Internet worldwide are not available or are limited, determining an analysis of the online behavior of SMEs in the European Union in terms of certain indicators.

On average, in 2014, $73.1 \%$ of SMEs in the European Union had a website or used a homepage for online promotion, registering an increase of $7 \%$ compared to 2010 . On the first places are Finland and Denmark with a growth rate of over $90 \%$, the last positions being held by Bulgaria and Romania, with a growth rate under 50\%. In the EU-27, the annual growth rate of the number of SMEs with a website or homepage increased continuously from 55.7\% in 2004 to $73.1 \%$ in 2014 (Table 7).

Annual percentage growth rates of SMEs

* having a website or homepage, EU-27 (2004-2014)
\begin{tabular}{|c|c|}
\hline Year & Annual percentage growth rates (\%) \\
\hline 2004 & 55.7 \\
\hline 2005 & 59.8 \\
\hline 2006 & 61.1 \\
\hline 2007 & 61.9 \\
\hline 2008 & 62.8 \\
\hline 2009 & 63.5 \\
\hline 2010 & 66.2 \\
\hline 2011 & 68.4 \\
\hline 2012 & 70.5 \\
\hline 2013 & 72.3 \\
\hline 2014 & 73.1 \\
\hline
\end{tabular}

Source: European Commission, 2015

Where: *10-249 persons employed; without financial sector 
In terms of promotion, an average of $24.6 \%$ of SMEs in EU-27 has paid for online advertising. Over $40 \%$ of small and medium sized enterprises in Denmark, Czech Republic and Finland allocated certain budgets for their online advertising campaigns, at the opposite pole from the European average being Hungary, France and Portugal, with a rate of less than $20 \%$ of SMEs.

Also, the social media sites which registered significant increases in terms of the number of users and the amount of posted, uploaded or downloaded information, are accessed by SMEs to promote their businesses, events, offers, and to communicate with current and potential customers etc. Thus, in Europe, an average of $35 \%$ of SMEs have used social media sites, the highest percentages being registered in Malta and Ireland (over $60 \%$ of SMEs), and lowest in Romania, Poland and Latvia (below 20\%). Compared with 2013, in 2014 there was an increase of 5\% of SMEs in the EU who have used social media.

The e-commerce is another means by which SMEs can develop their business and promote their products. It is an effective way to increase their revenue by selling products in the virtual environment or to reduce the costs by purchasing online the goods and services required at much lower prices. On average, $14.1 \%$ of European SMEs use e-commerce to sell products and $22 \%$ of them use this online tool to purchase various goods.

\section{Case studies on the online promotional campaigns of SMEs and their results}

Etilux is a company that sells B2B labels, it's headquarter being established in Liège, Belgium, in 1972. This company has gradually evolved through the expansion of headquarters and the development of new divisions, reaching a 16,6 million euros turnover in 2003 from 5.6 million euros in 1989. In 1997 the company launched the first version of the website, in 2008 being drawn up a new version that included case studies on the variety of services offered by the company. The creation of this site for promoting the company's products and services was a necessary issue because $45 \%$ of the turnover was generated by the external market, Etilux having clients from over 40 countries and a turnover of 21 million euros (European Commission, 2009).

The site etilux.com is an important promotional instrument, offering to the company the possibility of being closer to its customers, but also a way to increase its sales, the website including an e-commerce section with over 600 products. The site is translated into 6 languages and allows visitors to select the way they want to view information, according to their origin country.

The company noted that most of its customers still prefer the human contact in the process of purchasing the needed products, despite the facilities offered by the website. Consequently, Etilux tried to increase the attractiveness of the site and the users' confidence by:

- introducing photos and videos with the company's employees;

- presenting the contacting sections in the form of inducements, such as click to call, or click to chat;

- developing the company blog;

- promoting on social media using regular postings - Facebook (488 likes) Slideshare (30 Etilux documents that present the products and services of the company), Twitter (2,209 tweets) Google+ (190,441 views) LinkedIn (843 followers) and Youtube (9,085 views).

The posts on social media sites are different and are customized for each social network individually, meaning that Facebook is used for:

- posting pictures and messages from various events organized by the company (presentations, seminars) or from those attended by its personnel (fairs and exhibitions, projects for teenagers);

- sending greeting cards for holidays;

- promoting the awards obtained by the company;

- presenting the products, using 1-2 posts per week.

Also the posts on LinkedIn are adapted to this social network for business networking and include: invitations to some fairs in which the company is present with its own stand, vacancy 
announcements and presentations of company's products. The Etilux channel from Youtube includes: videos that present the company and its products, testimonials from customers and innovative solutions developed for clients, some of these clips being also integrated into the site etilux.com, in the sections in which the products are presented. Thus, addressing to the B2B segment, the company does not make multiple posts on Facebook/LinkedIn consisting of offers or messages for the general public (it does not aim the B2C segment). The information provided through these social media networks links to different sections of the site etilux.com (blog, newsletters, product pages etc.), as well as the company's Youtube channel. However, some of the posts from Google+ and Twitter are addressed to the general public and refer to sporting events, to the results achieved by social networks or to the news from various websites which have not necessarily the same profile as the Eilux Company.

Paris Normandie is a regional newspaper in France, which created in 2008 a Twitter account in order to increase the number of readers, employing a journalist-blogger to manage this project. Being a newspaper and given the speed with which the information travels today, the posts on Twitter are quite frequent, about 6-7 posts per hour. The newspaper's visibility has significantly increased through these posts and because they have generated the most views of the newspaper's articles, the posts from Twitter were integrated in a special section of the http://www.parisnormandie.fr/ site. So far, the Paris Normandie newspaper has made 51,000 posts on Twitter, it posted 1,731 pictures and videos, and has over 21,000 followers. Although the creation of an account on Twitter and promoting the publication through simple posts or the distribution of photos/videos is free, not all the entrepreneurs who have such accounts are able to obtain positive results using the social media. Even if the Paris Normandie newspaper has not paid directly for the publicity through social media, the results were obtained by hiring a person for this project and also by a careful selection of the information posted on social media and of the optimal methods for posting them

Another example of using online tools by SMEs in order to promote their business is the Frugi Company from Cornwall (UK) which produces organic clothes for mothers, children and newborns. In 2004 the company launched the http://www.cut4cloth.co.uk/ site starting from the need of the business' owners regarding the cloth diapers for their child. The day the site was launched there were six orders and their number gradually increased. In 2006 the owners decided to expand the business introducing in the offer clothing for children and products for breastfeeding. In 2008 cut4cloth became frugi, the headquarter was moved to an organic farm, and the turnover reached over 1 million euros. In terms of marketing, the company wanted to develop the customers' loyalty to the brand through blogging, social media sites and Web 2.0 tools (European Commission, 2009). The Frugi blog was created in November 2011 and currently there are made about 4 posts per month about the company's products, the customers' satisfaction, the charitable campaigns, the events in which the company is involved and also about special offers etc. Social media sites used for promoting the Frugi brand are: Facebook (24,720 likes), Twitter (6,260 tweets and 6,839 followers), Pintrest (700 pins, 512 followers), Google+ (83,554 views), Youtube (30 videos posted). On Facebook the company makes a post every day, most of the posts ending with questions or entreaties to customers. Thus, the post through which the Frugi Company asked for help to find a name for the new IT colleague named Matt has generated 117 comments and 33 likes. Also, the pictures posted on Facebook are framed in the design of the company's website (various animals, bright colors, funny fonts), and the way of communicating the information is friendly and suitable for the target group. The competitions organized by Frugi and promoted through postings on this social network generated more feedbacks, comments and shares of the posts. The updating of the information posted on the Frugi website, also the adaptation of the methods of communicating with customers through online environment and the continuous optimization of the site for search engines have improved its positioning in the search engines and generated an increase of the number of views and the conversion rate of the online users into customers. 


\section{Conclusions}

The SMEs are the engine of the economy and the online environment is one of the environments through which they can develop on long term. First, the SMEs are receivers of online information, this being collected by companies in the form of databases and offering the possibility to find more about their position on the market and its competitors and to identify various partners at national and international level, in order to exploit the ideas that underlie the innovative products and services through which the businesses differentiate themselves in the market. Secondly, the SMEs are transmitters of information and both free and paid online advertising tools are increasingly effective on the background of the increase of the number of Internet users and the development of online platforms for meeting the online consumers' needs. Through the online promotion tools the products of a local company can become known by a simple click (sending an e-mail with the company's offer, programming the display of a online banner for a certain segment of online users, posting a video or photo on social media sites which can become viral etc.) to consumers worldwide. In the last but not least, the Internet also generates revenues for SMEs through the e-commerce platforms.

Therefore, the SMEs in the European Union can both now and in the future to develop itself online with the help of the financing funds allocated to small and medium sized enterprises. EU supports the SMEs through the development of online networks and the initiation of special programs for the online environment, giving them the chance to exploit the opportunities arising from the annual increase of the number of online users and also from their preference of informing themselves using the Internet and of spending their free time on social networks or other platforms.

Another important aspect that SMEs should take into account refers to the need of collaborating with various specialists, both those from the marketing field, specialized in the online communication, and the programmers. Also, the investment in the online promotion must be a continuous one, the drawing up a website with some brief information and contact details of the company being considered insufficient. The SMEs have to ensure the transparency of the provided information, updating them permanently and highlighting the results obtained, the won projects, the attracted new customers etc. These measures could increase the confidence of the potential and actual customers and, implicitly, could improve the results obtained on medium and long term.

\section{References}

1. Balaban, D., 2009. Media communication (translated from Romanian: Comunicare mediatică), Triton Publishing House, Bucharest, p. 17.

2. Balint, A.O., 2013. From the traditional to the modern and complex agricultural companies that are using business intelligence tools, published in: Agrarian Economy and Rural Development - Realities and Perspectives for Romania, Vol. 4, University of Agronomic Sciences and Veterinary Medicine, Bucharest, p. 178.

3. Brown, B.C., 2006. How to use the Internet to advertise, promote and market your business or web site - with little or no money, Atlantic Publishing Group, Inc., Florida, p. 54.

4. Chiagouris L., Mohr I., 2004. An Evaluation of the Effectiveness of Internet Advertising Tools, Journal of Internet Commerce, Vol. 3(3)/2004, The Haworth Press, Inc., Philadelphia, Pennsylvania, p. 47.

5. DIW ECON, 2014. SME Performance Review 2013/2014 (13 May 2014), available at: http://ec.europa.eu/enterprise/policies/sme/facts-figures-analysis/performance

review/files/supporting-documents/2014/annual_report_database.zip [accessed at: 3 February 2015].

6. European Commission, 2005. The new SME definition. User guide and model declaration, Enterprise and Industry Publications, p. 14, available at: http://ec.europa.eu/enterprise/policies/sme/files/sme_definition/sme_user_guide_en.pdf [accessed at: 3 February 2015]. 
7. European Commission, 2009. Learning from Peers/e-Business case, p. 8 \& 55, available at: http://ec.europa.eu/enterprise/sectors/ict/files/e-bsn/learning_from_peersro.pdf [accessed at: 7 February 2015].

8. European Commission. Directorate - General for Enterprise and Industry, 2014. Annual Report on European SMEs 2013/2014 - A Partial and Fragile Recovery, July 2014, p. 35, available at: http://ec.europa.eu/enterprise/policies/sme/facts-figures-analysis/performancereview/files/supporting-documents/2014/annual-report-smes-2014_en.pdf [accessed at: 7 February 2015].

9. European Commission, 2014. European Enterprise Promotion Awards: Entrepreneurial education crucial for jobs creation. Press Release, Brussels, 25 June 2014, available at: https://www.google.ro/url? sa=t\&rct=j\&q=\&esrc=s\&source=web\&cd=2\&cad=rja\&uact=8\& ved=0CC0QFjAB\&url=http\%3A\%2F\%2Feuropa.eu\%2Frapid\%2Fpress-release_IP-14721_en.doc\&ei=gfoBVfeVIZHTaPv4goAN\&usg=AFQjCNHP14c6XuHfEwITHOTBHNrinjirw\&bvm=bv.88198703,d.d2s [accessed at: 3 February 2015].

10. European Commission, 2015. Digital Agenda for Europe, available at: http://digital-agendadata.eu/charts/see-the-evolution-of-an-indicator-and-compare-countries\#chart $=\{$ "indicatorgroup":"ebusiness","indicator":"E_WEB","breakdown":"ent_sm_xfin","unitmeasure":"pc_ent","ref-area":["EU27"]\} [accessed at: 3 March 2015].

11. European Free Trade Association (EFTA), 2015. EEA Agreement. Annex XII: Free movement of capital, p. 4, available at: http://www.efta.int/media/documents/legaltexts/eea/the-eea-agreement/Annexes\%20to\%20the\%20Agreement/annex12.pdf [accessed at: 2 March 2015].

12. International Telecommunications Union, 2014. Measuring the information - Society Report 2014, p. 15, available at: http://www.itu.int/en/ITUD/Statistics/Documents/publications/mis2014/MIS2014_without_Annex_4.pdf [accessed at: 10 February 2015].

13. Mac an Bhaird C., 2010. Resourcing Small and Medium Sized Enterprises. A Financial Growth Life Cycle Approach, Springer-Verlag Berlin Heidelberg, p. 9 -10.

14. Marin V., 2007. Direct Marketing Communication (translated from Romanian: Comunicarea în marketingul direct), Transilvania University Publishing House, Braşov, p. 129.

15. Netcraft, 2015. Web Server Survey, (24 February 2015), available at: http://news.netcraft.com/archives/2015/02/24/february-2015-web-server-survey.html [accessed at: 2 March 2015].

16. Rusăneanu A. E., 2014. Innovative Marketing for SMEs using Social Media, published in: Intercultural Management, vol. XVI, no. 3 (32), Iaşi, p. 72.

17. Soviany A., 2008. Life lived online - about social websites (translated from Romanian: Viaţa trăită online - despre site-urile de socializare), 6 November 2008, available at: http://www.revista22.ro/viata-traita-online-despre-site-urile-de-socializare-4967.html [accessed at: 2 March 2015].

18. Shimp T., Andrews J. C., 2013. Advertising, Promotion and Other Aspects of Integrated Marketing Communications, South-Western, Cengage Learning, Ohio, USA, p. 360.

19. Statista, 2015. Worldwide market share of leading search engines from January 2010 to January 2015, available at: http://www.statista.com/statistics/216573/worldwide-marketshare-of-search-engines/ [accessed at: 2 March 2015].

20. Statistic Brain Research Institute, 2015. Google Annual Search Statistics, January 9th 2015, available at: http://www.statisticbrain.com/google-searches/ [accessed at: 4 March 2015].

21. The Radicati Group, Inc., 2013a. Email Statistics Report 2013-2017 (April 2013), p. 2-5, available at: http://www.radicati.com/wp/wp-content/uploads/2013/04/Email-StatisticsReport-2013-2017-Executive-Summary.pdf [accessed at: 10 February 2015]. 
22. The Radicati Group, Inc., 2013b. Instant - Messaging Market 2013 - 2017 (September 2013), p. 4, available at: http://www.radicati.com/wp/wp-content/uploads/2013/09/InstantMessaging-Market-2013-2017-Executive-Summary.pdf [accessed at: 11 February 2015].

23. The Radicati Group, Inc., 2014. Email Statistics Report 2014-2018 (April 2014), p. 2-5, available at: http://www.radicati.com/wp/wp-content/uploads/2014/01/Email-StatisticsReport-2014-2018-Executive-Summary.pdf [accessed at: 11 February 2015]. 